\title{
Comparison of effects of unfractionated heparin and low molecular weight heparin on skin wound healing of rats $^{1}$
}

\author{
Comparação dos efeitos da heparina não fracionada e heparina de baixo peso molecular na \\ cicatrização de feridas na pele de ratos
}

\author{
Can Engin Durmaz, Aydin Ozkan ${ }^{\mathrm{II}}$, Bugra Senel ${ }^{\mathrm{III}}$, Hasan Alper Uyar ${ }^{\mathrm{IV}}$ \\ ${ }^{\mathrm{I}} \mathrm{PhD}$, DDS, Oral and Maxillofacial Surgeon, Oral and Maxillofacial Surgery Clinics, Diyarbakir Military Hospital, Diyarbakir, Turkey. Design of study \\ and surgical procedures. \\ "IPhD, DDS, Oral and Maxillofacial Surgeon, Oral and Maxillofacial Surgery Clinics, Diyarbakir Military Hospital, Diyarbakir, Turkey. Design and \\ scientific content of the study, manuscript writing. \\ IIIPhD, DDS, Oral and Maxillofacial Radiolog, Diyarbakir Military Hospital, Dental Service, Diyarbakir, Turkey. English language, manuscript writing. \\ ${ }^{\mathrm{IV}} \mathrm{PhD}$, DDS, Prosthodontist, Erzurum Military Hospital, Dental Service, Erzurum, Turkey. Acquisition of data, statistical analysis.
}

\begin{abstract}
PURPOSE: To compare the effects of unfractionated heparin (UH) and a low molecular weight heparin (LMWH) on skin wound healing of rats.

METHODS: Forty eight male Sprague-Dawley rats underwent $8 \mathrm{~mm}$ full thickness dorsal skin wounds and were randomly assigned to three equal groups. In experimental group A, heparin sodium was injected at a concentration of $1000 \mathrm{U} / \mathrm{kg}$. In experimental group B, enoxaparin was injected at a concentration of $1 \mathrm{mg} / \mathrm{kg}$. Physiologic saline $(0.5 \mathrm{ml})$ was administered to the control group. Injections were made subcutaneously, once daily, for seven days. At $7^{\text {th }}$ and $10^{\text {th }}$ days tissue samples were taken from all rats. Histologic examination of these tissues was made under light microscope and scored.

RESULTS: Histological examination showed a significant difference between the $7^{\text {th }}$ and $10^{\text {th }}$ day groups in wound healing. It was observed that wound healing of LMWH injected group is better. This difference is statistically significant at $10^{\text {th }}$ day.

CONCLUSIONS: Daily administration of single doses of unfractionated heparin and a low molecular weight heparin improves wound healing positively. Low molecular weight heparin induces wound healing more than unfractionated heparin.
\end{abstract}

Key words: Heparin, Low-Molecular-Weight. Wound Healing. Skin. Rats.

\section{RESUMO}

OBJETIVO: Comparar os efeitos da heparina não fracionada (HNF) e da heparina de baixo peso molecular (HBPM) na cicatrização de feridas cutâneas de ratos.

MÉTODOS: Quarenta e oito ratos machos Sprague-Dawley foram submetidos à ferida na pele dorsal com espessura total de 8mm e foram distribuídos aleatoriamente em três grupos iguais. No grupo experimental A, a heparina sódica foi injetada a uma concentração de $1000 \mathrm{U} / \mathrm{kg}$. No grupo experimental B, a enoxaparina foi injetada a uma concentração de $1 \mathrm{mg} / \mathrm{kg}$. Solução salina fisiológica ( $0,5 \mathrm{ml})$ foi administrada para o grupo controle. As injeções foram feitas por via subcutânea, uma vez por dia, durante sete dias. Nos dias $7^{\circ}$ e $10^{\circ}$ amostras de tecido foram obtidas de todos os ratos. O exame histológico destes tecidos foi realizado em microscópio de luz.

RESULTADOS: O exame histológico mostrou uma diferença significativa entre os grupos no $7^{\circ}$ e $10^{\circ}$ dias na cicatrização das feridas. Observou-se que a cicatrização de feridas do grupo com heparina de baixo peso molecular foi melhor. Esta diferença foi estatisticamente significante no $10^{\circ}$ dia. CONCLUSÕES: A administração diária de doses únicas de heparina não fracionada e de heparina de baixo peso molecular melhora a cicatrização de feridas. A heparina de baixo peso molecular induz melhor a cicatrização de feridas do que a heparina não fracionada.

Descritores: Heparina de Baixo Peso Molecular. Cicatrização de Feridas. Pele. Ratos. 


\section{Introduction}

The wound healing process in defined as a series of events that starts with inflammation and is followed by cell immigration, angiogenesis, provisional matrix synthesis, accumulation of collagen and re-epithelialization. This process is very complex and it consists of a complex interaction among inflammatory cells, biochemical mediators, extracellular molecules and microenvironment. Collagen is the most essential basal, skeletal protein employed in healing processes. The increase in collagen content during wound repair may be attributed to an increase of collagen synthesis and/or proliferation of fibroblasts ${ }^{1,2}$. Many factors can interfere with one or more phases of healing process, thus causing impaired wound healing. These factors include oxygenation, infection, age and sex hormones, stress, diabetes, obesity, medications, alcoholism, smoking, and nutrition may be considered $^{3}$.

Unfractionated heparin (UH) and low molecular weight heparin (LMWH) in treatment of deep vein thrombosis (DVT) are routinely used in the preoperative period. Heparin rapidly inhibits the anticoagulant activity mediated by anti-thrombin III (AT III). Anti-thrombin slowly interacts with thrombin without heparin. Although heparin-AT III complex inactivates thrombin, LMWH and anti- thrombin complex is more specific for Factor $\mathrm{Xa}^{4,5}$. In recent years because of short half-life of heparin causes bleeding LMWH has preferred and it was reported that for the patients treated with LMWH propagation of thrombus, risk of thromboembolism and especially major bleeding incidence are significantly lower than heparin ${ }^{6}$. Besides length of stay in hospital is shorter and hospital charges are more lower for the patients treated with LMWH. These features make LMWH reliable for DVT prophylaxis and treatment ${ }^{7}$.

How does using heparin derivatives on wound healing after surgery is still a controversial subject. While protecting the patient from thromboembolism, safety of operative field shouldn't be compromised. For this reason it is very important to know if $\mathrm{UH}$ and LMWH which are commonly used in clinic is effective or not. Purpose of this study is to compare the effects of UH and LMWH on wound healing histologically in rats underwent full thickness wound.

\section{Methods}

The study protocol was reviewed and approved by the Research Review Committee and the Animal Care Committee at the Gulhane Military Medical Academy (Ankara, Turkey). Threemonth-old male Sprague-Dawley rats (n:48) weighting between 275 to $325 \mathrm{~g}$ were used. Forty eight rats were randomly assigned to three equal groups including experimental group A, experimental group B and control group. Each group consisted of 16 rats and all were given standard care and dietary regimen during the experimental period.

\section{Anesthesia and surgical procedure}

Rats were injected $4 \mathrm{mg} / \mathrm{kg}$ body weight xylasine $\mathrm{HCl}$ (alfazine) for premedication and $60 \mathrm{mg} / \mathrm{kg}$ body weight ketamine (alfamine) for general anesthesia. The skin of the rats was shaved in the dorsa-lateral region and full thickness skin wounds were established by $8 \mathrm{~mm}$ diameter of punches. In experimental Group A, heparin sodium was injected subcutaneously at a concentration of $1000 \mathrm{U} / \mathrm{kg}$. In experimental Group B, enoxaparin was injected subcutaneously at a concentration of $1 \mathrm{mg} / \mathrm{kg}$. Physiologic saline $(0.5 \mathrm{ml})$ was administered to the control group. Subcutaneously once daily injections were begun twelve hours before skin excision, six hours after surgery and continued postoperative period for seven days. After induction of high dose general anesthesia the rats, experimental and control were sacrificed on days $7^{\text {th }}$ and $10^{\text {th }}$ and tissue samples were taken.

\section{Histological analysis}

The wound area was dissected and cut into $1.5 \times 1.5 \mathrm{~cm}$. full thickness strip including intact tissue. In order to examine fibroblastic proliferation, epithelialization of healing construction and phases of collagen histologically, tissue samples were taken from the wounded area at 7 th and 10th days. They were fixed into $10 \%$ formaldehyde for two days then these blocks were embedded in paraffin and $4-5 \mu \mathrm{m}$ sections were cute from paraffin blocks by using microtome (Microm HM355s, Japan) for microscopic examination. Then paraffin blocks were stained by hematoxylineosin and scored. For each sample, 10 different fields at a magnification of $\times 20$ were examined and histopathological findings were categorized for the presence of epidermal regeneration, collagen bundles, fibroblastic proliferation and vascularity ${ }^{8,9}$ (Table 1). While the samples exactly show the features of the phase that they are in were scored as 1 , samples that are between two phases was scored as 0.25 point. 
TABLE 1 - Microscopic criteria for evaluation and scoring of wound healing.

\begin{tabular}{cccc}
\hline $\begin{array}{c}\text { Criterion/ } \\
\text { Scores }\end{array}$ & $\mathbf{0}$ & $\mathbf{1}$ & $\mathbf{2}$ \\
\hline $\begin{array}{c}\text { 1. Epidermal } \\
\text { regeneration }\end{array}$ & $\begin{array}{c}\text { Absence of } \\
\text { epithelium }\end{array}$ & $\begin{array}{c}\text { Single-layer } \\
\text { epithelium with } \\
\text { partial closure }\end{array}$ & $\begin{array}{c}\text { Multilayer } \\
\text { epithelium } \\
\text { with complete } \\
\text { closure }\end{array}$ \\
$\begin{array}{c}\text { 2. Collagen } \\
\text { fibers }\end{array}$ & $\begin{array}{c}\text { Very thin, } \\
\text { sparse and } \\
\text { irregular }\end{array}$ & $\begin{array}{c}\text { Thin, partly } \\
\text { sparse and } \\
\text { irregular }\end{array}$ & $\begin{array}{c}\text { Dense and } \\
\text { regular }\end{array}$ \\
$\begin{array}{c}\text { 3. Numbers of } \\
\text { fibroblasts }\end{array}$ & A few & Moderate & A lot \\
4. Vascularity & Absence & $\begin{array}{c}\text { Occasional } \\
\text { presence and } \\
\text { light scattering }\end{array}$ & $\begin{array}{c}\text { Confluence of } \\
\text { cells }\end{array}$ \\
\hline
\end{tabular}

\section{Statistical analysis}

Data were analyzed using SPSS for Windows v.15.0. Kruskal-Wallis was used to compare means of continuous variables for different groups. The groups which were determined difference were compared in multiple pairs by Mann-Whitney-U test with Bonferoni correction significance was set at $\mathrm{p}<0.05$.

\section{Results}

Histologic analysis of wound healing sites at $7^{\text {th }}$ day

Control group: It was considered that organization of collagen fibrils in dermis layer were sparse and irregular (Figure 1a).

Group A: Dermis was not well organized and characterized by sparse collagen fibrils that were partly organized (Figure 1b).

Group B: Epidermal organization was close to normal and neovascularization areas were determined beneath the epidermis layer. Collagen fibrils in dermis layer were more regular than control group (Figure 1c).

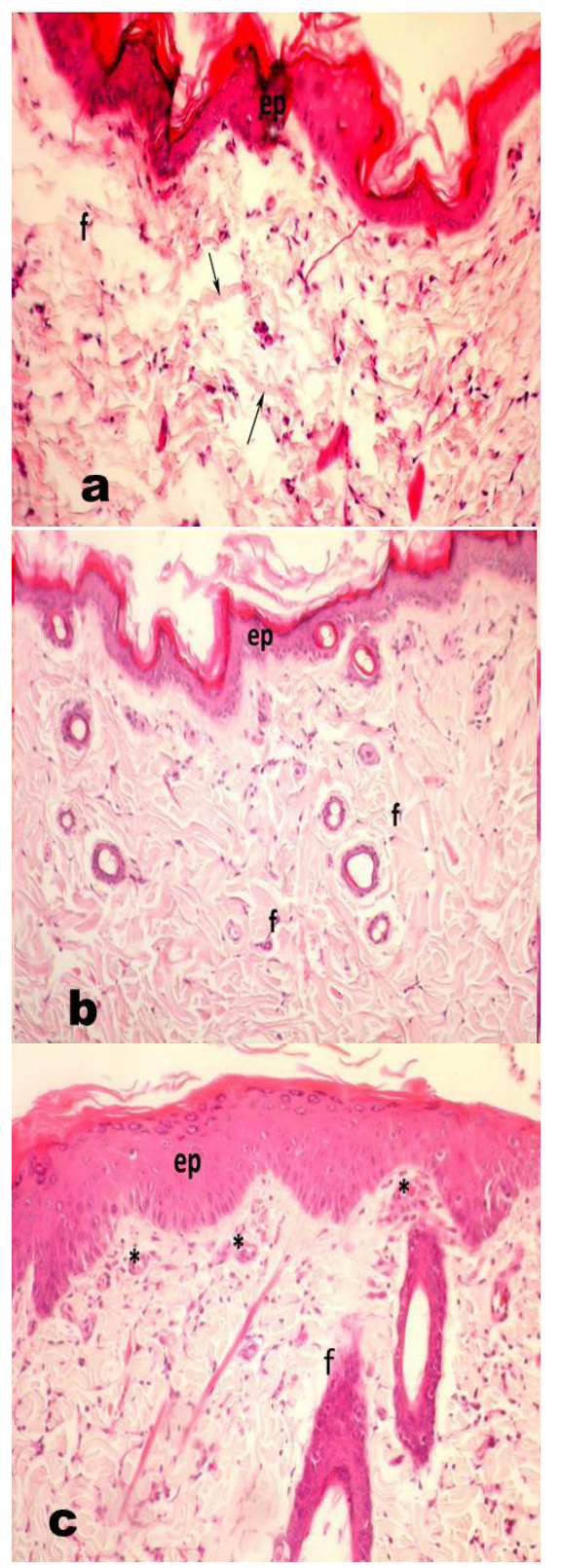

FİGURE 1- Histological sections of wound healing at 7th day. a) In the control group, collagen fibrils are appeared sparse, thin and irregular (head to black arrows). b) In the group A, collagen fibrils in dermis layer is more regular than control group. c) In the group B, appearance of epidermis layer is closed to normal and blood vessels $(*)$ are occurred beneath the epidermis layer. Epidermis (ep), fibroblast (f), H\&E (20x).

\section{Histologic analysis of wound healing sites at $10^{\text {th }}$ day}

Control group: It was considered that collagen fibrils in dermis layer were sparse and irregular. Dermal organization was better than control group at 7 th day. Hemorrhagic areas were determined beneath the epidermis layer (Figure 2a).

Group A: Collagen fibrils were sparse and irregular in some places but hair follicles were much more than other groups (Figure 2b).

Group B: Collagen fibrils were more regular than 
group A. Mononuclear cell infiltration was observed in between epidermis and dermis layers (Figure 2c).

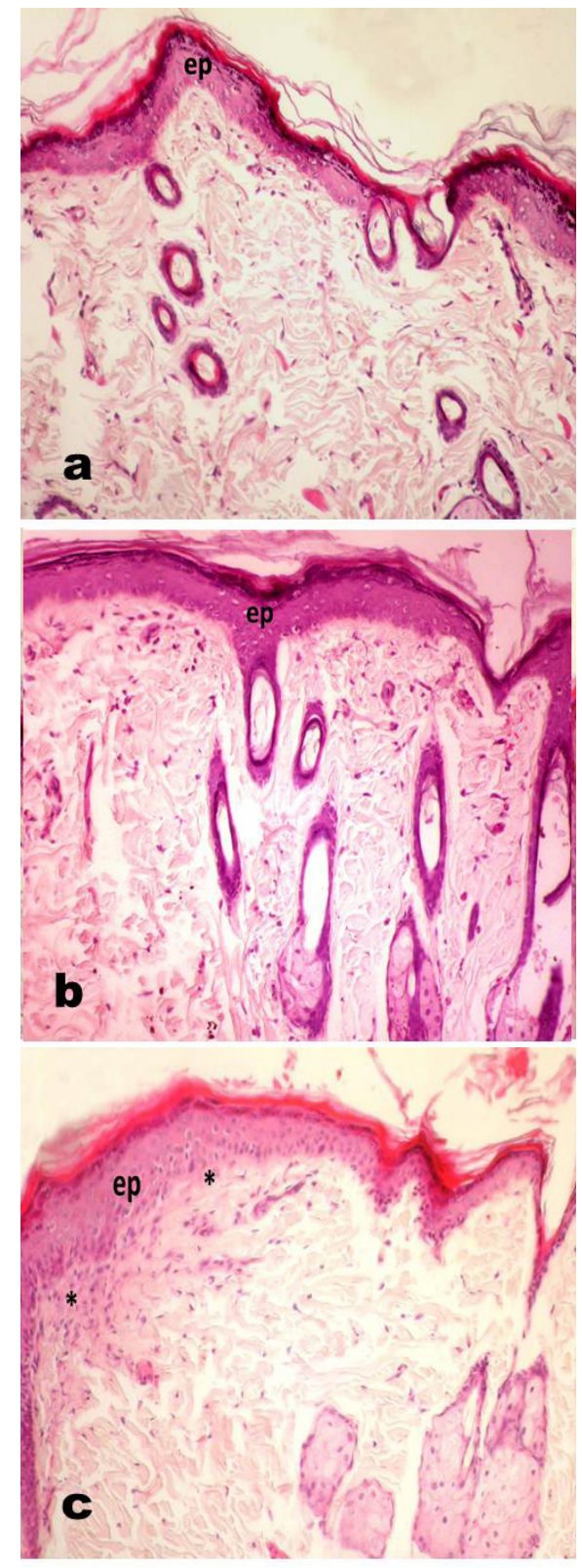

FÍGURE 2 - Histological sections of wound healing at 10th day. a) In the control group, collagen fibrils are appeared sparse and irregular. b) In the group A, collagen fibrils are appeared partially sparse and irregular in some places. c) In the group B, mononuclear cells infiltration is presented between epidermis and dermis layers. Epidermis (ep), H\&E (20x).

After evaluation of the groups among themselves according to the histological scoring, experimental Group B had the best healing at $7^{\text {th }}$ and $10^{\text {th }}$ days ( $7^{\text {th }}$ day: Mean \pm SD $1.4 \pm 0.13$ $10^{\text {th }}$ day: Mean \pm SD 1.75 \pm 0.19$)$ and difference between groups is statistically significant $\left(\mathrm{p}^{\mathrm{x}}: 0.000\right)$. When we evaluate the groups one by one in experimental group healing was the same and in other groups healing is better at 10th day but the difference is not statistically significant (Table 2).

TABLE 2- A statistical comparison of histological values within and between groups according to days (KruskalWallis test was used for finding the values of $\mathrm{p}$ ). N: number, SD: Standard deviation, Min: minimum, Max: Maximum, * statistically significant, $\mathrm{p}^{\mathrm{x}}<0.05$ statistically significant, $\mathrm{p}^{\mathrm{y}}<0.05$ statistically significant.

\begin{tabular}{ccccc}
\hline $\begin{array}{c}\text { Days/ } \\
\text { Groups }\end{array}$ & $\begin{array}{c}\text { Control } \\
(\mathbf{n}=\mathbf{1 6})\end{array}$ & $\begin{array}{c}\text { Group A } \\
(\mathbf{n}=\mathbf{1 6})\end{array}$ & $\begin{array}{c}\text { Group B } \\
(\mathbf{n}=\mathbf{1 6})\end{array}$ & \\
\hline & Mean \pm SD & Mean \pm SD & Mean \pm SD & $\mathbf{P}^{\mathbf{x}}$ \\
\cline { 2 - 5 } $\mathbf{7}^{\text {th }}$ day & $0.44 \pm 0.11$ & $1.0 \pm 0.19$ & $1.4 \pm 0.13$ & $0.000^{*}$ \\
$\mathbf{1 0}^{\text {th }}$ day & $1.0 \pm 0.22$ & $1.0 \pm 0.19$ & $1.75 \pm 0.19$ & $0.000^{*}$ \\
\hline $\mathbf{P}^{\mathbf{y}}$ & 0.17 & 0.90 & & \\
\hline
\end{tabular}

Evaluation of the groups in pairs at 7 th day there is no significant difference between experimental groups but comparison of the experimental groups and control group in pairs a significant difference was found ( $\left.\mathrm{p}^{\mathrm{z}}: 0.000\right)$ and also at 10th day a significant difference was found between experimental groups and between experimental Group B and control group ( $\mathrm{p}^{\mathrm{z}: 0.003)}$ (Table 3).

TABLE 3 - Comparison of the histologic values between the groups in pairs. (Mann-Whitney -U test was used for finding the value of $\mathrm{p}$. Bonferoni correction was made after the test.) * statistically significant $\mathrm{pz}<0.05$ statistically significant.

\begin{tabular}{ccc}
\hline Groups/ Days & $\mathbf{7}^{\text {th }}$ day & $\mathbf{1 0}^{\text {th }}$ day \\
\cline { 2 - 3 } & $\mathbf{P}^{\mathbf{z}}$ & $\mathbf{P}^{\mathbf{z}}$ \\
\hline Group A-Control & $0.000^{*}$ & 0.15 \\
Group B -Control & $0.000^{*}$ & $0.003^{*}$ \\
Group A-Group B & 0.06 & $0.003^{*}$ \\
\hline
\end{tabular}

\section{Discussion}

The normal healing includes hemostatic/inflammatory phases, maturation phase and remodeling phase. An effect of heparin on wound healing is still controversial subject. Studies examined the wound healing claimed that UH and LMWH shows anti-proliferative effects on fibroblast $\mathrm{t}^{10,11}$, endothelial cells ${ }^{12}$, osteoblasts $^{13}$ and angiogenesis ${ }^{14}$. Heparin administration may 
be caused hemorrhagic complications and increase the serohemorrhagic drainage after surgery. Prolonged sero-hemorrhagic drainage may have changed the content of wound fluid and so it influences the thrombin formation. A decrease in thrombin and fibrin clot formation causes negative effect in the early phases of healing ${ }^{15}$. In our study we did not encountered macroscopically hematoma or bleeding is during heparin administration. Heparin might be expected to impair the early phases of healing process but in this study histologically we found the numbers of fibroblasts are more and collagen fibrils are more regular in experimental groups at $7^{\text {th }}$ and $10^{\text {th }}$ day then control group.

The influence of heparin administration on wound healing in rats has been investigated by Cen et al. ${ }^{16}$. They received subcutaneously heparin on experimental burned rats and this caused a significant shortening of healing time. Our results on LMWH are in line with this observation. Similar effect has been observed by Kweon et al. ${ }^{17}$ who administered heparin/chitosan complex topically. After two weeks of treatment the dorsal full thickness skin excision was nearly completely healed when it was compared with the respective controls. Li et al. ${ }^{18}$ have shown that the promotion of LMWH on the gastric ulcer healing was independent from the anticoagulant effect. In the present study we analyzed the effects of UH and a LMWH on wound healing process at $7^{\text {th }}$ and $10^{\text {th }}$ days. Gunerhan et al..$^{19}$ examined the effects of UH and LMWH on wound healing and indicated a positive effect between experimental groups at $7^{\text {th }}$ day but the difference was not significant. In our study when we compared the effects of $\mathrm{UH}$ and LMWH on wound healing, similarly the difference was not significant between experimental groups at $7^{\text {th }}$ day but wound healing was faster for experimental group that heparin used at $10^{\text {th }}$ day $\left(p^{z}: 0.003\right)$.

Oliveira et $a l .^{20}$ histopathologically examined the abdominal wall healing in rats treated with enoxaparin for one week and sacrificed at the end of the $3^{\text {th }}, 7^{\text {th }}$ and $14^{\text {th }}$ days after laparotomy surgery was performed. The result of histopathological examinations the organization of collagen was better in control groups than experimental groups enoxaparin used at $7^{\text {th }}$ day but there was no difference between groups at $14^{\text {th }}$ day. This shows that heparin has no effect on final maturation of wound healing at $14^{\text {th }}$ day. In our study statistically significant difference was observed between groups at $7^{\text {th }}$ and $10^{\text {th }}$ day in terms of wound healing. This result shows that heparin has effect on wound healing until the $10^{\text {th }}$ day.

One of the most important problems regarding studies with heparin related to dose and duration of application. In most of the studies concerning wound healing treatment dosage of
DVT was preferred for heparin. For example Oliveira et al. ${ }^{20}$ used enoxaparin $(1 \mathrm{mg} / \mathrm{kg} /$ day $)$ on abdominal wound healing for seven days. Arikan et al. ${ }^{21}$ had a similar study. They applied $1 \mathrm{mgr} / \mathrm{kg}$ enoxaparin per day for seven days on abdominal wound healing. Also Kus et al..$^{22}$ performed a similar study for the same period and dose of application. Another dose problem of heparin studies on wound healing are direct comparison between UH and LMWH doses is not possible due to the differences in units. During our study we have not found a literature related with optimal dose for wound healing. Therefore, adhering to existing literatures, we determined application dose of enoxaparin as $1 \mathrm{mgr} / \mathrm{kg}$ and heparin dose as $1000 \mathrm{U} / \mathrm{kg}$. In addition, adhering to duration of heparin existing prophylaxis we made application to rats during seven days.

\section{Conclusions}

The low molecular weight heparin preparations have more attractive pharmacokinetic profile than UH preparations and this feature makes them more popular in the last decades. Histologically both of the preparations increased the rate of reepithelialization, therefore, unfractionated heparin and low molecular weight heparin play a positive role in tissue remodeling but when effects of these two preparations compared with each other low molecular weight heparin has more positive effects on wound healing process.

\section{References}

1. Gurtner GC, Werner S, Barrandon Y, Longaker MT. Wound repair and regeneration. Nature. 2008;453(7193):314-21.

2. Amadeu TP, Amedea BS, Deoliveira MG, Monte-Alto-Costa A. Nitric oxide donor improves healing if applied on inflammatory and proliferative phase. J Surg Res. 2008;149(1):84-93.

3. Guo S, Dipietro LA. Factors affecting wound healing. J Dent Res. 2010;89(3):219-29.

4. Green D, Hirsh J, Heit J,Prins M, Davidson B, Lensing AWA. Low molecular weight heparin: a critical analysis of clinical trials. Pharmacol Rev. 1994;46(1):89-109.

5. Weitz J. New anticoagulant strategies. Current status and future potential. Drugs. 1994;48(4):485-97.

6. Ji H, Li SP, Cheng X, Cheng HR, Ng TB, Li P, Li N. S. Antithrombotic effects of low-molecular-weight heparin calcium (LMWH-Ca) in experimental models. Gen Pharmocol. 1999;33(2):207-11.

7. Knight KK, Wong J, Hauch O, Wygant G, Aguilar D, Ofmann JJ. Economic and utilization outcomes associated with choice of treatment for venous thromboembolism in hospitalized patients. Value Health. 2005;8(3):191-200.

8. Eldad A, Weinberg A, Breiterman S, Chaouat M, Palanker D, Ben-Bassat H. Early nonsurgical removal of chemically injured tissue enhances wound healing in partial thickness burns. Burns. 1998;24(2):166-72.

9. Dogan N, Ucok C, Korkmaz C, Ucok O, Karasu HA. The effects of articaine hydrochloride on wound healing: an experimental study. $\mathrm{J}$ 
Oral Maxillofac Surg. 2003;61(12):1467-70.

10. Tiozzo R, Reggiani D, Cingi MR, Bianchini P, Osima B, Calandra S. Effect of heparin derived fractions on the proliferation and protein synthesis of cells in culture. Thromb Res. 1991;62(3):177-88.

11. Carroll LA, Koch RJ. Heparin stimulates production of bFGF and TGF-beta 1 by human normal, keloid, and fetal dermal fibroblasts. Med Sci Monit. 2003;9(3):97-108.

12. Khorana AA, Sahni A, Altland OD, Francis CW. Heparin inhibition of endothelial cell proliferation and organization is dependent on molecular weight. Arterioscler Thromb Vasc Biol. 2003;23(11):2110-5.

13. Street J, Power C, Wakai A, Wang JH, McGuinness A, Redmond HP. Low molecular weight heparins induced osteoblast apoptosis: a putative mechanism for iatrogenic osteopenia. J Bone Joint Surg Br. 2002;84-B:7.

14. Collen A, Smorenburg SM, Peters E, Lupu F, Koolwijk P, van Noorden C, van Hinsbergh VW Unfractionated and low molecular weight heparin affect fibrin structure and angiogenesis in vitro. Cancer Res. 2000;60(21):6196-200.

15. Esen E, Cila E, Ozoğul C, Taşçi AG, Sipahioğlu S, Gemalmaz HC, Oztürk AM, Doğramaci Y. The effect of low-molecularweight heparin on rat tendon healing. Acta Orthop Traumatol Turc. 2009;43(1):54-61

16. Cen Y, Luo P, Yan X. The effect of heparin on the deep second-degree burn in scalded rats. Zhonghua Shao Shang Za Zhi. 2001;17(3):1746.

17. Kweon DK, Song SB, Park YY. Preparation of water-soluble chitosan/heparin complex and its application as wound healing accelerator. Biomaterials. 2003;24(9):1595-601.

18. Li Y, Shin VY, Cheuk CY, Liu ES, Cho CH. A 3.0-kDa low molecular weight heparin promotes gastric ulcer healing in rats. Aliment Pharmacol Ther. 2001;15(12):2009-17.

19. Gunerhan Y, Koksal N, Gul O, Uzun MA, Guneş P, Adaleti R. Effects of unfractionated heparin and low-molecular-weight heparin on colonic anastomoses in the presence of experimental peritonitis. Eur Surg Res. 2006;38(3):353-7.

20. Oliveira PG, Sousa JB, Reys LG, Magalhães AV, Rabelo Fde S, Muniz KC. Effects of enoxaparin on the healing of abdominal wall in rats: study on breaking strength and histopathology. Acta Cir Bras. 2006;21(4):247-51.

21. Arikan S, Adas G, Barut G, Toklu AS, Kocakusak A, Uzun H, Kemik O, Daduk Y, Aydin S, Purisa S. An evaluation of low molecular weight heparin and hyperbaric oxygen treatment in the prevention of intra-abdominal adhesions and wound healing. Am J Surg. 2005;189(2):155-60.

22. Kus E, Bienkiewicz A. Subcutaneous low molecular weight heparin administration promotes wound healing in rats. Pathophysiology. 2006;13(2):81-4.

\section{Correspondence:}

Aydin Ozkan

Oral and Maxillofacial Surgery Clinics

Diyarbakir Military Hospital

Yenisehir 21100, Diyarbakir, Turkey

Tel.: +904122288220 / +905325234207

Fax: +904122236237

ydnozkan@yahoo.com

Received: April 26, 2012

Review: June 25, 2012

Accepted: July 30, 2012

Conflict of interest: none

Financial source: none

${ }^{1}$ Research performed at the Experimental Animal Laboratory, Gulhane Military Medical Academy, Ankara, Turkey. 